Abstracta Iranicacta Iranica

Revue bibliographique pour le domaine irano-aryen

Volume 32-33 | 2013

Comptes rendus des publications de 2009-2010

\title{
Deniz Kaptan. From Xenophon to Kritoboulos: Notes on Daskyleion and the Satrapal Court
}

\section{Astrid Nunn}

\section{(2) OpenEdition}

1 Journals

\section{Édition électronique}

URL : http://journals.openedition.org/abstractairanica/40343

DOI : 10.4000/abstractairanica.40343

ISSN : 1961-960X

Éditeur :

CNRS (UMR 7528 Mondes iraniens et indiens), Éditions de l'IFRI

\section{Édition imprimée}

Date de publication : 1 décembre 2013

ISSN : 0240-8910

\section{Référence électronique}

Astrid Nunn, «Deniz Kaptan. From Xenophon to Kritoboulos: Notes on Daskyleion and the Satrapal Court », Abstracta Iranica [En ligne], Volume 32-33| 2013, document 86, mis en ligne le 01 juillet 2016, consulté le 05 octobre 2020. URL : http://journals.openedition.org/abstractairanica/40343 ; DOI : https:// doi.org/10.4000/abstractairanica.40343

Ce document a été généré automatiquement le 5 octobre 2020.

Tous droits réservés 


\title{
Deniz Kaptan. From Xenophon to Kritoboulos: Notes on Daskyleion and the Satrapal Court
}

\author{
Astrid Nunn
}

\section{RÉFÉRENCE}

Deniz Kaptan. « From Xenophon to Kritoboulos: Notes on Daskyleion and the Satrapal Court », in : Bruno Jacobs, Robert Rollinger, éds., « Der Achämenidenhof / The Achaemenid Court ». Akten des 2. Internationalen Quolloquiums zum Thema « Vorderasien im Spannungsfeld klassischer und altorientalischer Überlieferungen ", Landgut Castelen bei Basel, 23.-25. Mai 2007. Wiesbaden, 2010, p. 829-852. (Classica et Orientalia(CLeO), 2)

1 Ce que Xénophon a écrit ne suffisant pas pour connaitre Daskyleion, D. Kaplan associe la description écrite de cette ville aux vestiges archéologiques qui sont aptes à illustrer la vie de la cour satrapale. Un de ces objets est un brûle-encens que l'on retrouve aussi bien sur une stèle de Daskyleion, que sur les reliefs de Persépolis ou sur les vases ioniens. Les quelques remarques de Xénophon sur la vie dans les satrapies peuvent ainsi être replacées dans le contexte plus large de la vie des élites dans l'Empire.

\section{AUTEURS}

ASTRID NUNN

Université de Munich 